\title{
Factors Related to the Incidence of Contact Dermatitis In-Fisherman on the Spermonde Island
}

\author{
Agus Bintara Birawida ${ }^{1 *}$, Anwar Mallongi ${ }^{1}$, M. Fais Satrianegara ${ }^{2}$, Ain Khaer $^{3}$, Appolo Appolo $^{4}$, Muhammad Restu ${ }^{5}$ \\ ${ }^{1}$ Department of Environmental Health, School of Public Health, Hasanuddin of University, Makassar, Indonesia; ${ }^{2}$ Department \\ of Environmental Health; ${ }^{3}$ Faculty of Medicine and Health Sciences, Alauddin Islamic State University, Makassar, Indonesia; \\ ${ }^{4}$ Health Polytechnic Makassar, Polytechnic Makassar, Makassar, Indonesia; ${ }^{5}$ Faculty of Forestry, Hasanuddin University, \\ Makassar, Indonesia
}

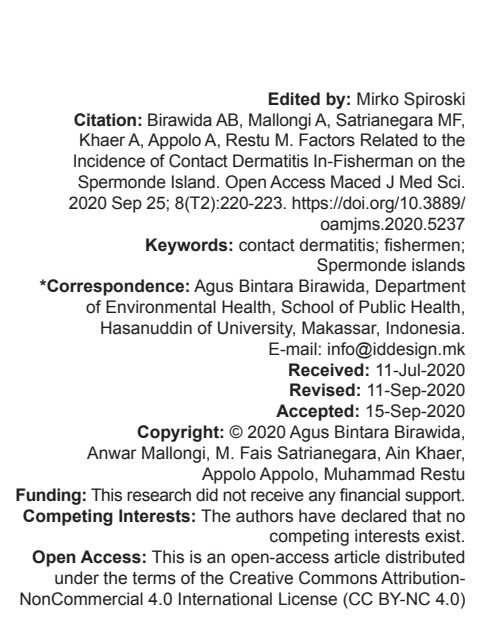

\section{Abstract}

BACKGROUND: Many factors can influence the occurrence of dermatitis; this factor is divided into two, namely exogenous and endogenous factors. Fishermen are jobs that are susceptible to disease in dermatitis, especially contact dermatitis in the small island.

AIM: This study aimed to determine the factors associated with the incidence of contact dermatitis in fishermen on the Spermonde islands.

METHODS: This study was an observational analytic study using a cross-sectional design study. This research was conducted on Lae-Lae, Barrang Lompo, and Lumu-Lumu Island in 2019. Samples in this study were 110 fishermen obtained using Accidental sampling techniques. Data collection is using research instruments.

RESULTS: Data analysis performed was univariate and bivariate analysis with a Chi-square test. Based on the results of the study, the research variables related to factors affecting contact dermatitis in fishermen in the Spermonde Islands were a history of skin diseases $(p=0.000)$, use of PPE $(p=0.000)$, personal hygiene $(p=$ $0.000)$, and working period $(p=0.003)$ while unrelated factors are age $(p=0.373)$.

CONCLUSION: Fishermen should pay more attention to four factors, namely the history of skin diseases, the use of PPE, hygiene, and work period, to avoid contact dermatitis.

\section{Introduction}

The use of simple equipment causes the body of fishermen to be in direct contact with water, causing environmental-based diseases, one of which is a disease caused by work. Occupational diseases occur in fishermen caused by exposure to hazardous substances that occur during work [1]. Based on the types of organs that can experience abnormalities due to work, the skin is the organ most frequently affected by occupational diseases. Unconsciously, the work environment can be found materials, goods, or elements that can be harmful to the skin, irritate the skin, cause skin allergies, cause skin infections, or cause changes in skin pigment when attached to the skin, can even lead to skin cancer [2].

Dermatitis is a disease that can occur due to exposure to the skin. Dermatitis is inflammation of the skin in the epidermis and dermis in response to the influence of exogenous and endogenous factors that cause clinical abnormalities in the form of polymorphic efflorescence (erythema, edema, papules, vesicles, squama, and lichenification) and itching complaints [3]. The cause of this dermatitis can come from outside the body (exogenous), for example, chemicals detergents, acids, bases, oil, cement), physical (light, temperature), microorganisms (bacteria, fungi), or from the body (endogenous), for example, atopic dermatitis [4].

Based on data from the Barrang Lompo Community Health Center whose work areas cover six islands (Barrang Lompo Island, Barrang Caddi Island, Bonetambung Island, Lumu-Lumu Island, Lanjukang Island, and Langkawi Island), the incidence of dermatitis in the last 3 years, namely in 2016 dermatitis ranks fifth in the ten largest disease patterns are 545 cases, then in 2017 it increased to 916 cases and decreased in 2018 by 651 cases [5]. Based on the description above, the authors conducted a study to determine the relationship of environmental sanitation and the behavior of fishermen to the incidence of dermatitis in the Spermonde Islands.

\section{Materials and Methods}

This study was an observational analytic crosssectional study design. The location of this study is on 
three islands in the city of Makassar, namely on the islands of Lae-Lae, Barrang Lompo, and Lumu-Lumu. This research was carried out in February-August 2019. The population of this study was all fishermen in the islands of Lae-Lae, Barrang Lompo, and Lumu-Lumu. The sampling technique uses non-probability sampling, namely, accidental sampling. Data on factors related to the incidence of contact dermatitis in fishermen include the dependent variable (the incidence of dermatitis) and the independent variables (age, years of service, history of skin diseases, use of personal protective equipment, and personal hygiene). While for primary data collection, researchers were assisted by enumerators and health workers. Secondary data were obtained in the form of dermatitis data from related institutions, namely, Barrang Lompo Puskesmas, Riskesdas 2008 data, Makassar city health profile 2014, and literature related to this study. Data analysis was performed to determine the relationship between independent variables (age, years of service, history of skin diseases, use of personal protective equipment, and personal hygiene) on the dependent variable (incidence of dermatitis). The statistical test used is Chi-square using the following formula:

$$
X^{2}=\frac{N(|a d-b c|-n / 2)^{2}}{(A+b)(C+d)(b+d)}
$$

\section{Results}

\section{The incidence of contact dermatitis}

The incidence of contact dermatitis is obtained by diagnosis from a healthcare provider. The diagnosis is done by knowing the symptoms that cause contact dermatitis. The incidence of contact dermatitis in fishermen can be seen in Table 1.

Table 1: Fisherman distribution based on contact dermatitis in the Spermonde Islands

\begin{tabular}{|c|c|c|c|c|c|c|}
\hline \multirow[t]{3}{*}{ The incidence of contact dermatitis } & \multicolumn{6}{|c|}{ Frequency } \\
\hline & \multicolumn{2}{|c|}{ Lae-Lae } & \multicolumn{2}{|c|}{ Barrang Lompo } & \multicolumn{2}{|c|}{ Lumu-Lumu } \\
\hline & $\mathrm{n}$ & $\%$ & $\mathrm{n}$ & $\%$ & $\mathrm{n}$ & $\%$ \\
\hline Positive & 14 & 46.7 & 23 & 46 & 13 & 43.3 \\
\hline Negative & 16 & 53.3 & 27 & 54 & 17 & 56.7 \\
\hline Total & 30 & 100 & 50 & 100 & 30 & 100 \\
\hline
\end{tabular}

Based on the data in Table 1, it explains that the number of positive fishermen experiencing contact dermatitis was found on Barrang Lompo Island by 23 people $(46 \%)$. Although the number of fishermen who had negative dermatitis more than those who tested positive for dermatitis, the number of fishers who tested positive for dermatitis was quite high, almost half of the total sample.
Table 2: Relationship between age and contact dermatitis in fishermen in Spermonde Islands, Makassar City

\begin{tabular}{|c|c|c|c|c|c|c|}
\hline \multirow[t]{3}{*}{ Age } & \multicolumn{4}{|c|}{ The incidence of contact dermatitis } & \multirow[t]{3}{*}{$\mathrm{n}$} & \multirow[t]{3}{*}{$\mathrm{p}$} \\
\hline & \multicolumn{2}{|c|}{ Yes } & \multicolumn{2}{|l|}{ No } & & \\
\hline & $\mathrm{n}$ & $\%$ & $\mathrm{n}$ & $\%$ & & \\
\hline Young & 38 & 48.1 & 41 & 51.9 & 26 & $p=0,373$ \\
\hline Old & 12 & 38.7 & 19 & 61.3 & $53 \mathrm{c}$ & \\
\hline Total & 50 & & 60 & & 110 & \\
\hline
\end{tabular}

\section{The age and the incidence of contact} dermatitis in fishermen

The relationship between age and the incidence of contact dermatitis in fishermen can be seen in Table 2.

The results of the study in Table 2 show that fishermen who are in the younger age category suffer more from contact dermatitis, amounting to 38 people compared to other age categories. Whereas the older age category suffered fewer contact dermatitis, that is, 12 people compared to other age categories. The value of $p=0.373(p>0.005)$ means that the hypothesis $\mathrm{Ho}$ is accepted and $\mathrm{Ha}$ is rejected. Then, it can be interpreted that there is no relationship between age and the incidence of contact dermatitis in fishermen in the Spermonde Islands of Makassar.

\section{Duration of work with contact dermatitis}

The relationship of work period with the incidence of contact dermatitis in fishermen is shown in Table 3.

Table 3: Relationship between work duration and contact dermatitis in fishermen in Spermonde Islands, Makassar City

\begin{tabular}{|c|c|c|c|c|c|c|}
\hline \multirow[t]{3}{*}{ Duration of work (Years) } & \multicolumn{4}{|c|}{ The incidence of contact dermatitis } & \multirow{3}{*}{$\begin{array}{l}\text { Total } \\
\mathrm{n}\end{array}$} & \multirow[t]{3}{*}{$\mathrm{p}$} \\
\hline & \multicolumn{2}{|c|}{ Yes } & \multicolumn{2}{|l|}{ No } & & \\
\hline & $\mathrm{n}$ & $\%$ & $\mathrm{n}$ & $\%$ & & \\
\hline$\geq 5$ & 43 & 54.4 & 36 & 45.6 & 79 & $p=0.003$ \\
\hline$<5$ & 7 & 22.6 & 24 & 77.4 & 31 & \\
\hline Total & 50 & & 60 & & 110 & \\
\hline
\end{tabular}

The results of the study in Table 3 show that the majority of fishermen with more than 5 years of work experience contact dermatitis in the amount of 43 people $(54.4 \%)$. Whereas fishermen who work < 5 years' experience fewer contact dermatitis, namely 7 people $(22.6 \%)$. The number of fishermen who did not suffer from contact dermatitis was more than 5 years, namely 36 people, whereas fishermen with $<5$ years of service experience fewer than 24 people with contact dermatitis. The value of $p=0$, $(<0.005)$ which means that $\mathrm{Ho}$ is rejected and $\mathrm{Ha}$ is accepted. Hence, it can be interpreted that there is a relationship between the lengths of work with the incidence of contact dermatitis in fishermen in the Spermonde Islands of Makassar.

\section{History of skin diseases with the incidence of contact dermatitis}

The relationship between the history of skin disease and the incidence of contact dermatitis in fishermen in Table 4 
Table 4: Relationship between skin disease history and incidence of contact dermatitis in fishermen in the Spermonde Islands, Makassar City

\begin{tabular}{|c|c|c|c|c|c|c|}
\hline \multirow[t]{3}{*}{ The history of skin disease } & \multicolumn{4}{|c|}{ The incidence of contact dermatitis } & \multirow{3}{*}{$\begin{array}{l}\text { Total } \\
\mathrm{n}\end{array}$} & \multirow[t]{3}{*}{$\mathrm{p}$} \\
\hline & \multicolumn{2}{|l|}{ Yes } & \multicolumn{2}{|l|}{ No } & & \\
\hline & $\mathrm{n}$ & $\%$ & $\mathrm{n}$ & $\%$ & & \\
\hline History & 31 & 96.9 & 1 & 3.1 & 32 & \\
\hline No history & 19 & 24.4 & 59 & 75.6 & 78 & $p=0.00$ \\
\hline Total & 50 & & 60 & & 110 & \\
\hline
\end{tabular}

The results of the study in Table 4 show that the category of fishermen who have a history of skin disease and suffer from contact dermatitis are 31 people $(96.9 \%)$ higher than those who have no history and suffer from contact dermatitis only 19 people (24.4\%). While fishermen who did not suffer from contact dermatitis more had no history of skin disease, as many as 59 people $(75.6 \%)$ while those who had a history of skin disease as much as one person $(3.1 \%)$. The value of $p=0.000(<0.005)$ means that $\mathrm{Ho}$ is rejected and $\mathrm{Ha}$ is accepted. Hence, it can be interpreted that there is a relationship between the history of skin diseases and the incidence of contact dermatitis in fishermen in the Spermonde Islands of Makassar.

\section{Use of personal protective equipment (PPE) with the incidence of contact dermatitis}

The relationship between the use of PPE and the occurrence of contact dermatitis in fishermen is shown in Table 5.

Table 5: Relationships between personal protective equipment use and the incidence of contact dermatitis on fishermen in the Spermonde Islands of Makassar

\begin{tabular}{|c|c|c|c|c|c|c|}
\hline \multirow[t]{3}{*}{ PPE } & \multicolumn{4}{|c|}{ The incidence of contact dermatitis } & \multirow{3}{*}{$\begin{array}{l}\text { Total } \\
\mathrm{n}\end{array}$} & \multirow[t]{3}{*}{$\mathrm{p}$} \\
\hline & \multicolumn{2}{|c|}{ Yes } & \multicolumn{2}{|l|}{ No } & & \\
\hline & $\mathrm{n}$ & $\%$ & $\mathrm{n}$ & $\%$ & & \\
\hline No complete & 43 & 65,2 & 23 & 34,8 & 66 & \\
\hline Complete & 7 & 15,9 & 37 & 84,1 & 44 & $\mathrm{p}=0,0$ \\
\hline Total & 50 & & 60 & & 110 & \\
\hline
\end{tabular}

The results of the study in Table 5 show that fishermen who are included in the category of incomplete PPE use more contact dermatitis in the amount of 43 people $(65.2 \%)$, compared to fishermen who use a complete PPE only seven people $(15.9 \%)$. While fishermen who did not suffer from contact dermatitis were more included in the category of complete PPE use, as many as 37 people (84.1\%) compared to those using incomplete PPE that were 23 people (34.8\%). The value of $p=0,000(p<0,005)$ means that Ho is rejected and $\mathrm{Ha}$ is accepted. Hence, it can be interpreted that there is a relationship between the uses of PPE with the incidence of contact dermatitis in fishermen in the Spermonde Islands of Makassar.

Table 6: Relationship between individual hygiene and the occurrence of contact dermatitis in fishermen in Spermonde Islands, Makassar City

\begin{tabular}{|c|c|c|c|c|c|c|}
\hline \multirow[t]{3}{*}{ Individual hygiene } & \multicolumn{4}{|c|}{ The incidence of contact dermatitis } & \multirow{3}{*}{$\begin{array}{l}\text { Total } \\
\mathrm{n}\end{array}$} & \multirow[t]{3}{*}{$\mathrm{p}$} \\
\hline & \multicolumn{2}{|c|}{ Yes } & \multicolumn{2}{|l|}{ No } & & \\
\hline & $\mathrm{n}$ & $\%$ & $\mathrm{n}$ & $\%$ & & \\
\hline Not good & 15 & 100 & 0 & 0.0 & 15 & $p=0,000$ \\
\hline Good & 35 & 36.8 & 60 & 84.1 & 95 & \\
\hline Total & 50 & & 60 & & 110 & \\
\hline
\end{tabular}

\section{Personal hygiene with the incidence of} contact dermatitis

Based on research has been done, the data obtained about the relationship between individual hygiene and the incidence of contact dermatitis in fishermen in Table 6.

The results of the study in Table 6 show that fishermen who suffer from contact dermatitis and are included in poor individual hygiene are as many as 15 people. While fishermen who suffer from contact dermatitis and have good hygiene are more as many as 35 people. Sixty fishermen do not suffer from contact dermatitis and are included in the category of good personal hygiene. The value of $p=0.000(p<$ 0.005 ) means that $\mathrm{Ho}$ is rejected and $\mathrm{Ha}$ is accepted. Then, it can be interpreted that there is a relationship between individual hygiene and the incidence of contact dermatitis in fishermen in the Spermonde Islands of Makassar.

\section{Discussion}

Respondents in this study were 110 fishermen. The respondents are on several islands such as (Laelae Island, Barrang Lompo Island, and Lumu-Lumu Island). Based on age distribution, most fishermen are included in the young category and the least are fishermen who are in the old category. This states that most respondents were of productive age.

Of all the respondents, it was found that those with contact dermatitis were 50 people, and those who did not have contact dermatitis were 60 people. The fishermen who experienced contact dermatitis was highest affected in the arm of the hand by $28.2 \%$. The high incidence of contact dermatitis on the arm of the hand is caused because when the fishermen are working, most fishermen do not wear clothes that cover all parts of the hands and also gloves so they cannot protect the hands from the dangers that can cause contact dermatitis.

In this study, one of the variables assessed was the length of service of fishermen. Fishermen who are included in the category have a working period of $\geq$ 5 years (long) more than fishermen who work $<5$ years (new). Fishermen who work long hours can increase the chance of contact dermatitis from fishermen who have a new working period.

Individual hygiene in this study is divided into two categories, namely the good category and the bad category. More fishermen who had personal hygiene were included in the good category at $86.4 \%$, while fishermen who were included in the category had less personal hygiene at $13.6 \%$. This shows that more fishermen pay attention to personal hygiene than those who do not. 
Individual hygiene is very influential on health, especially skin health [7] in fishermen because fishermen who incidentally work at sea that can cause skin diseases if they do not maintain their hygiene properly.

The incidence of contact dermatitis that occurs in fishermen can also be caused by fishermen themselves. During data collection, researchers found many fishermen who did not care about their safety. Some fishermen do not use personal protective equipment so that it can increase the possibility of irritation from the workplace environment. According to several testimonies from respondents who did not wear personal protective equipment, this was due to fishermen who claimed that they were lazy to wear gloves. Respondents who fall into the good category in the use of PPE are less that is equal to $40 \%$ while respondents who fall into the bad category are more equal to $60 \%$.

In the bivariate analysis, the results of the Chi-square and Fisher's exact statistical tests were independent and dependent variables. The variables associated with the incidence of contact dermatitis are variables of skin disease history, years of service, personal hygiene, and the use of PPE, while the variables not related to contact dermatitis are age.

The conclusion of the study of factors related to the incidence of contact dermatitis in fishermen, namely: There is no relationship with age of contact dermatitis in fishermen in the Spermonde Islands, Makassar City, but there is a relationship between the history of skin diseases, years of service, use of personal protective equipment, and personal hygiene with the incidence of contact dermatitis in fishermen in the Spermonde Islands of Makassar City.

\section{References}

1. Loddé B, Cros P, Roguedas-Contios AM, Pougnet R, Lucas D, Dewitte JD, et al. Occupational contact dermatitis from protein in sea products: Who is the most affected, the fisherman or the chef? J Occup Med Toxicol. 2017;12(1):4. https://doi. org/10.1186/s12995-017-0150-0 PMid:28203266

2. Harahap LS. Gambaran Gejala Gangguan Kulit Pada Nelayan di Lingkungan 30 Gudang Arang Kelurahan Belawan I Kecamatan Medan Belawan Tahun 2010. Medan, Indonesia: Universitas Sumatera Utara; 2011. https://doi.org/10.29103/ aa.v4i1.320

3. Frosch PJ, John SM. Clinical Aspects of Irritant Contact Dermatitis. New York: Springer-Verlag; 2011. p. 305-45. https:// doi.org/10.1007/978-3-642-03827-3_16

4. Menaldi SL. IImu Penyakit Kulit dan Kelamin. Jakarta: Badan Penerbit Fakultas Kedokteran Universitas Indonesia; 2015. https://doi.org/10.15395/mkb.v47n4.620

5. Makassar, Indonesia: Puskesmas Barang Lompo; 2018.

6. Böhme M, Wickman M, Lennart Nordvall S, Svartengren M, Wahlgren CF. Family history and risk of atopic dermatitis in children up to 4 years. Clin Exp Allergy. 2003;33(9):1226-31. https://doi.org/10.1046/j.1365-2222.2003.01749.x PMid:12956743

7. Ramdan IM, IImiah SH, Firdaus AR. Occupational irritan contact dermatitis among shipyard workers in Samarinda, Indonesia. J Kesehatan Masyarakat. 2018;14(2):239-46. https://doi. org/10.15294/kemas.v14i2.13417 